\title{
Clarifying researchers' subjectivity in qualitative addiction research
}

\author{
Michael Egerer ${ }^{1}$, Matilda Hellman ${ }^{1}$ \\ ${ }^{1}$ Centre for Research on Addiction, Control, and Governance CEACG, University of Helsinki, Finland
}

\begin{abstract}
Aims: In addiction research, non-constructionist traditions often question the validity and reliability of qualitative efforts. This study presents techniques that are helpful for qualitative researchers in dissecting and clarifying their subjective interpretations.

Methods: We discuss three courses of action for inspecting researchers' interpretations when analyzing focus-group interviews: (i) adapted summative content analysis, (ii) quantification of researchers' expectations; and (iii) speaker positions. While these are well-known methodological techniques in their own rights, we demonstrate how they can be used to complement one another.

Results: Quantifications are easy and expeditious verification techniques, but they demand additional investigation of speaker positions. A combination of these techniques can strengthen validity and reliability without compromising the nature of constructionist and inductive inquiries.

Conclusions: The three techniques offer valuable support for the communication of qualitative work in addiction research. They allow researchers to assess and understand their own initial impressions during data collection and raw analysis. In addition, they also serve in making researchers' subjectivity more transparent. All of this can be achieved without abandoning subjectivity, but rather making sense of it.
\end{abstract}

\section{Introduction}

Researchers' subjectivity and impressions are valuable parts of research conduct and are important in all stages of qualitative research: when outlining the study, during field work, and in the final stages of analysis and reporting (Krieger, 1985; Hubbard, Backett-Milburn, \& Kemmer, 2001; Mauthner \& Doucet, 2003; Lindh, 2015; Denzin, 1994). Researchers and their emotions are part of the data, and intuition and gut feelings can serve as beacons, drawing attention to unexpected findings (Kleinman \& Copp, 1993; Lindh, 2015).

Nonetheless, researchers' subjectivity is often difficult to introduce to health research, which is dominated by realist quantitative methods and a positivist research angle. Addiction research is a field that predominately builds evidence in line with quantitative traditions inherited from epidemiology, medicine, and cognitive sciences (Hellman et al., in press; Babor et al., 2017; Rhodes, Stimson, Moore, \& Bourgois, 2010). Research is evaluated most typically in view of classic validity and reliability constructs that are not applicable to constructionist approaches (e.g., Golafshani,
2003; Guest, MacQueen, \& Namey, 2012). This might be one reason why qualitative research has remained marginal. In a recent study of the content of 40 established addiction journals, the proportion of published articles involving a qualitative methodology is only $11 \%$ (Hellman et al., in press). "[I]nsufficient detail on the ... method and analytical process" (Neale et al., 2013, p. 447) has been expressed as one of the most typical reasons for the rejection of qualitative work.

Often the centrality of subjectivity in qualitative research is mistaken as a relativism of "ad hoc assumptions." There are, however, some helpful techniques for scaffolding the relevance of qualitative work in evaluation settings where this view is represented. Tong, Sainsbury, and Craig (2007) have collated a list of quality criteria for reporting qualitative research in their review study. Their encompassing list of criteria emphasizes transparency and avoiding bias by ensuring that reporting includes details about the research team, study design, and study analysis. Berends and Johnston (2005) have used a multi-coding scheme to control for bias in their study on service users of drug treatment. They even involved treatment personnel and drug users themselves, in order to increase the credibility of their

Correspondence: Michael Egerer, Centre for Research on Addiction, Control, and Governance CEACG, Faculty of Social Sciences, P.O. Box 9 (Siltavuorenpenger

1A), FIN-00014 University of Helsinki

Email: michael.egerer@helsinki.fi

Financial support: Finnish Foundation for Alcohol Studies.

Declaration of interest: None

Keywords: addiction, social workers, qualitative methods, focus groups, subjectivity 
analysis. As the authors themselves acknowledged, the price for the increased control of researcher's subjectivity was, however, a decrease in the depth of analysis.

Research traditions can be crudely placed upon a continuum between the positivist and constructivist stances. While the positivist paradigm works on the assumption that an objective reality exists out there to be studied in systematic fashion, the constructivist paradigm holds the world to be subjectively constructed and contextual; this applies to the constructivist inquiries which cannot (and do not wish to) shed light upon universal truths, but instead seek to map out co-constructed subjective realities (Spencer, Pryce, \& Walsh, 2014). The qualitative methodology has initially originated from the constructivist tradition, and thereby aims at thick descriptions of contextual subjective realities and meanings (e.g., Geertz, 1973). Strategies attempting to increase the caliber of qualitative research often aim to tame its qualitative character, in order to mimic validation criteria inherent to the hegemonic quantitative and positivist research methodologies, rather than make rich use of its qualitative potential. Expectations and suggestions often endorse altogether avoiding the inclusion of valuable core components from the underlying constructivist epistemology. While different concepts have been discussed to replace the positivist evaluative criteria of validity and reliability (e.g., with credibility and dependability), the justifications for carrying out changes often follow positivistic logic on research conduct: subjectivity must be avoided and objectivity must be maintained throughout research. Thus, subjectivity, while firstly acknowledged as important contextualization, is nevertheless often inevitably treated as a bias. Research conduct more properly informed by a constructivist paradigm would instead consider subjectivity to be both important and necessary (Krieger, 1985).

As qualitative addiction researchers, our aim in this article is to tackle this imbalance, and to suggest and discuss three techniques by which researchers' subjectivity can be substantiated and operationalized. The first of these techniques is an adapted summative content analysis, in which we identify and count labels used by interviewees. The second includes a summation of researchers' expectations, which makes use of our own assumptions about our interviewees. Thirdly, we employ a semiotic analysis of speaker positions. We contend that our suggested strategies are transparent enough to connect to and be justified within the governing research paradigms of the addiction research field, while still acknowledging researchers' emotions and gut feelings as inherent parts of data analysis within qualitative research. To illustrate our case, we use data from a focus-group study conducted with German social workers (SW) on the topic of problem drinking, gambling, and eating.

\section{Table 1}

Interviewee Background

\begin{tabular}{|c|c|c|c|c|c|c|}
\hline $\begin{array}{l}\text { Interviewee } \\
\text { identifier }\end{array}$ & $\begin{array}{l}\text { Focus } \\
\text { group }\end{array}$ & Sex & $\begin{array}{l}\text { Year of } \\
\text { birth }\end{array}$ & $\begin{array}{l}\text { Work } \\
\text { experience } \\
\text { (years) }\end{array}$ & Field of social work & Qualification \\
\hline 1 & 1 & Female & 1965 & 14 & $\begin{array}{l}\text { Youth welfare office and general social } \\
\text { service }\end{array}$ & $\begin{array}{l}\text { Social work/pedagogy } \\
\text { (university) }\end{array}$ \\
\hline 2 & 1 & Female & 1967 & 10 & Social services of the district & $\begin{array}{l}\text { Social work/pedagogy } \\
\text { (university) }\end{array}$ \\
\hline 3 & 1 & Female & 1954 & 13 & $\begin{array}{c}\text { Youth welfare office and general social } \\
\text { service }\end{array}$ & $\begin{array}{l}\text { Sociology } \\
\quad \text { (university) }\end{array}$ \\
\hline 4 & 2 & Female & 1960 & 19 & $\begin{array}{c}\text { Psychiatric services for children and } \\
\text { adolescents }\end{array}$ & $\begin{array}{l}\text { Social work } \\
\quad \text { (polytechnic) }\end{array}$ \\
\hline 5 & 2 & Female & 1958 & 19 & $\begin{array}{l}\text { Psychiatric services for children and } \\
\text { adolescents }\end{array}$ & $\begin{array}{l}\text { Social work } \\
\quad \text { (polytechnic) }\end{array}$ \\
\hline 6 & 3 & Female & 1959 & 21 & Welfare office (employable age) & $\begin{array}{l}\text { Social work and pedagogy } \\
\text { (not reported if polytechnic or } \\
\text { university) }\end{array}$ \\
\hline 7 & 3 & Female & 1954 & 24 & $\begin{array}{c}\text { General social services (for people in } \\
\text { employable age) }\end{array}$ & $\begin{array}{l}\text { Pedagogy } \\
\quad \text { (university) }\end{array}$ \\
\hline 8 & 3 & Female & 1952 & 28 & $\begin{array}{c}\text { General social services (for people in } \\
\text { employable age) }\end{array}$ & $\begin{array}{l}\text { Social work and pedagogy } \\
\text { (not reported if polytechnic or } \\
\text { university) }\end{array}$ \\
\hline 9 & 3 & Female & 1957 & 20 & $\begin{array}{c}\text { General social services (for people in } \\
\text { employable age) }\end{array}$ & $\begin{array}{l}\text { Social work and pedagogy } \\
\text { (not reported if polytechnic or } \\
\text { university) }\end{array}$ \\
\hline 10 & 3 & Female & 1954 & 30 & $\begin{array}{c}\text { General social services (for people in } \\
\text { employable age) }\end{array}$ & $\begin{array}{l}\text { Social work and pedagogy } \\
\text { (not reported if polytechnic or } \\
\text { university) }\end{array}$ \\
\hline 11 & 3 & Female & 1958 & 27 & $\begin{array}{c}\text { General social services (for people in } \\
\text { employable age) }\end{array}$ & $\begin{array}{l}\text { Social work and pedagogy } \\
\text { (not reported if polytechnic or } \\
\text { university) }\end{array}$ \\
\hline 12 & 4 & Female & 1958 & 30 & Youth welfare office & $\begin{array}{l}\text { Social work/pedagogy } \\
\text { (university) }\end{array}$ \\
\hline 13 & 4 & Male & 1960 & 25 & Youth welfare office & $\begin{array}{l}\text { Social work/pedagogy } \\
\text { (university) }\end{array}$ \\
\hline
\end{tabular}




\section{Methods and Data}

The material that will be used to demonstrate the application of the aforementioned techniques consists of four focus groups of SWs, with 13 participants in total. The focusgroup interviews were conducted in the context of a larger research consortium studying images of addiction in a crosscultural framework. All but one of the participants were female and had work experience ranging from 10 to 30 years. Group sizes varied between two and six participants. These were natural groups, and participants normally worked together in four municipal social offices in three major German cities. Participants were recruited through contact with heads of social offices. We chose regular municipal SWs as gatekeepers of addiction: they had no special training in addiction, yet they were regularly confronted with addiction problems and had to deal with them and decide whether referral to specialized services was warranted (Egerer, 2015a, 2015b).
In line with reception analysis, the point of departure in our group interview method (Sulkunen \& Egerer, 2009) was in the acknowledgment of the dynamic meaning-making relations between texts, technologies, and interpretive audiences (e.g., Laughey, 2007). During the focus-group interviews the participants were shown film clips and then encouraged to openly discuss them. The interviewees "filled in" the offered narratives by referring to their own knowledge and beliefs (Törrönen, 2002; Sulkunen \& Egerer, 2009).

In the interview protocol, nine film clips from international fictional movies depicting instances of problematic alcohol, gambling, and eating behavior were shown; see Egerer (2010) for a detailed description. The discussions were selfled by the interviewees. The moderator's role was only to explain the interview setting and to run the stimulus clips. Data were analyzed with the help of the MaxQData software. The study adhered to the ethical principles of the Finnish Advisory Board on Research Integrity.

Table 2

Labels in Discussions on Problem Drinking

\begin{tabular}{|c|c|c|c|c|c|}
\hline & $\underset{1}{\text { Group }}$ & $\begin{array}{c}\text { Group } \\
2\end{array}$ & $\begin{array}{c}\text { Group } \\
\mathbf{3}\end{array}$ & $\underset{4}{\text { Group }}$ & Total \\
\hline Mother & 4 & 0 & 0 & 0 & 4 \\
\hline Frustration drinker [Frusttrinker] & 0 & 1 & 0 & 0 & 1 \\
\hline Fellow $[\operatorname{der} T y p]$ & 1 & 1 & 0 & 0 & 2 \\
\hline Maori people/Russian & 1 & 1 & 0 & 0 & 2 \\
\hline Fucking Russians [Schei $\beta$ Russen] & 1 & 0 & 0 & 0 & 1 \\
\hline Stepfather & 1 & 0 & 0 & 0 & 1 \\
\hline Addict sick [Suchtkranker] & 0 & 1 & 1 & 0 & 2 \\
\hline Drunk & 1 & 0 & 0 & 0 & 1 \\
\hline Old one & 1 & 0 & 0 & 2 & 3 \\
\hline Drunkard [Säufer] & 0 & 0 & 1 & 3 & 4 \\
\hline Drinker & 0 & 0 & 3 & 0 & 3 \\
\hline Father & 4 & 1 & 0 & 1 & 6 \\
\hline Drunk bum [besoffener Penner] & 0 & 1 & 0 & 0 & 1 \\
\hline Dependent/Addict [Abhängiger] & 2 & 0 & 0 & 0 & 2 \\
\hline Addict [Süchtiger] & 0 & 0 & 2 & 0 & 2 \\
\hline Wino $[$ Alki $]$ & 8 & 0 & 0 & 0 & 8 \\
\hline Human [Mensch] & 0 & 2 & 5 & 0 & 7 \\
\hline Social drinker [Geselligkeitstrinker] & 0 & 0 & 1 & 0 & 1 \\
\hline Alcohol sick [Alkoholkranker] & 0 & 0 & 2 & 0 & 2 \\
\hline Man & 2 & 2 & 7 & 0 & 11 \\
\hline Alcoholic & 8 & 6 & 4 & 8 & 26 \\
\hline Person & 0 & 0 & 2 & 0 & 2 \\
\hline Total & 34 & 16 & 28 & 14 & 92 \\
\hline
\end{tabular}

\section{Results}

When analyzing the interview data with the SWs, we observed that interviewees' perspectives materialized in similar ways: the same differences in opinion regarding drinking and gambling appeared in several different discussions (Egerer, 2015a, 2015b). However, the underlying core constructs for representing human nature appeared to stem from various competing logics. Stated more plainly, some groups held more negative attitudes toward persons with addictions, irrespective of the problems being discussed. The groups seemed to vary in outlook on human capabilities more generally. Particularly, one of the groups (Group 1) was seen to take a more pessimistic and at times even offensive stance regarding persons experiencing depicted problems. In particular, their views contrasted starkly with those from Group 2.

Adapted summative content analysis 
To clarify this subjective impression, we started out by identifying some of the labels used by interviewees for people with disorders pertaining to drinking, gambling and food in the SWs' discussions. We then proceeded to count how often the SWs used terms which, to our understanding, tended to belittle the people talked about. This quantification draws on quantitative linguistics, such as Zipf's law on the frequency of words and their inherent importance according to the number of times they are used (i Cancho \& Solé, 2001), and basic content analysis by which the appearance of themes is thought to reflect the salience of these themes in the material (Holsti, 1969; Bryman, 2003). It corresponds to a summative content analysis of labels (Hsieh \& Shannon, 2005). Quantifications in terms of portions and amounts also form a natural part of qualitative research in cases where researchers observe, for example, that the majority of participants or a low portion of interview data addresses specific issues (Becker, 1970). Labels were employed in all focus-group discussions, but Group 1 tended to employ them to a greater extent and employed more negative labels (Table 2).

We were surprised that Group 2, which initially appeared especially positive in their demeanor, used the label "drunk bum" [besoffener Penner] within their discussion. The importance of contextualizing divergent cases in qualitative analysis (Silverman, 2006) became particularly evident after further examination of the specific usage of the derogative "drunk bum" label. The SWs referred to this label as an example of critical perspectives expressed in society when dealing with homelessness. The number of times labels were used did not guarantee an accurate impression of discussion content, and instead these data needed to be cross-checked with their specific usage and contextual connotations.

The second technique for checking subjective impressions concerns researchers' assumptions based on prior knowledge about interviewees' characteristics. Our surprise at discovering offensive labeling in one of the focus groups may have resulted from our own expectations of what professional SWs are meant to represent. In the study design, we had selected SWs as representatives of an attentive profession associated with high ethical standards and values (Butrym, 1976; Bamford, 1990; Banks, 2001). Respect for people, a belief in the social nature of humankind, and a belief in the capacity for people to change have been expressed as core values integrated into the education of social workers and the conduct of their profession (Butrym, 1976, p. 48). These prevailing assumptions may also have influenced our expectations regarding the nature of the interviewees' assertions.

Table 3

\begin{tabular}{|c|c|c|c|c|c|c|}
\hline \multicolumn{7}{|c|}{ Vumerical Overview of Discussion on Social Work Values } \\
\hline Focus group & $\begin{array}{l}\text { Respect for } \\
\text { person }(+)\end{array}$ & $\begin{array}{l}\text { Respect for } \\
\text { person (-) }\end{array}$ & $\begin{array}{c}\text { Belief in social } \\
\text { nature }(+)\end{array}$ & $\begin{array}{c}\text { Belief in social } \\
\text { nature (-) }\end{array}$ & $\begin{array}{c}\text { Belief in } \\
\text { capacity to } \\
\text { change (+) }\end{array}$ & $\begin{array}{c}\text { Belief in } \\
\text { capacity to } \\
\text { change (-) }\end{array}$ \\
\hline Group 1 & 8 & 20 & 95 & 39 & 29 & 32 \\
\hline Group 2 & 29 & 1 & 63 & 7 & 30 & 14 \\
\hline Group 3 & 48 & 11 & 55 & 18 & 26 & 14 \\
\hline Group 4 & 11 & 36 & 33 & 9 & 3 & 24 \\
\hline$\Sigma$ & 96 & 68 & 246 & 73 & 88 & 84 \\
\hline
\end{tabular}

Prior knowledge and assumptions are a natural part of "sociologically constructed" codes (Strauss, 1987). In this case, they were constructed based on our expectations of certain core values implicit within social work, as proposed by Butrym (1976). In order to interrogate our own assumptions, we coded interviewee statements that either aligned with or else critically questioned these values. In Table 3 we have assembled a numerical overview of utterance frequency.

In comparison to a word and label search, as per our first technique, this strategy went one step further in interpretative analysis; the expression of values in the data could not have been recognized through a word search or listing out of labels.

Due to differences in group sizes and variance of frequency for coded utterances, the numerical overview could not be used to compare groups' utterances between one another directly. Instead, we used it to first acquire some indication of the ratio of utterances within the different groups and to then compare these ratios between groups.

Our initial impressions were that Group 1 expressed the least amount of empathy whereas Group 2 expressed the most. Group 3 and 4 generated no specific intuitive impression of either low or high empathy. Based on Table 3, our initial impressions were corroborated for Group 1, which showed the least respect for persons suffering from the discussed problems and had mixed beliefs regarding people's capacity to change. Group 2, in comparison, had the highest proportion of coded utterances of respect.

In contrast to our initial impressions, the second quantification technique allowed us to identify negative attitudes in Group 4 as well. In Groups 1 and 4, many of the protagonists from the film clips were evaluated negatively based on their appearance. Alun, a character in one of the stimulus clips on alcohol problems, wasn't deemed a person that "a woman would like to look at a second time" 
(Interviewee 12, Group 4). Group 2 instead evaluated the same person in a starkly different manner:

Interviewee 5: Whereupon, he still was a relatively young man. And if he would look more after himself, he perhaps would not be that unattractive that he would not be able to succeed in life. That, well, he was not that washed-up that everything would be in vain. (Group 2)

Group 2 (as well as the majority of Group 3) also expressed a considerable belief in the human ability to change. Group 4 and Interviewee 6 (of Group 3) showed a more pessimistic attitude concerning people's abilities to change for the better. In Group 1 the questioning of human abilities to change, and the possibilities of social work to help people do so, led to a vivid discussion between two participants. Interviewee 3 held the opinion that people have free will and can therefore quit an addiction. Interviewee 1 , on the other hand, felt that they could only prevent the "biggest shit" and that "the poor sods (children taken into custody) [have lost already] any good chances in their lives."

\section{Speaker positions}

The first two techniques were able to clarify which of the groups held positive impressions on the subjects discussed, through a focus on expressed utterances and attitudes. However, they were not capable of explaining why initial impressions did not suggest that Group 4 also held negative attitudes. The reason why Group 1 struck us as representing an especially negative image of human nature also remained puzzling, as in fact at least one of the participants expressed an optimistic view on people's possibility to change.

The third technique attended to this issue by developing an analysis on speakers' positions. This is a well-established and valuable approach for recognizing the meaning-making achieved through the dynamics and interaction of speakers (Runcieman, 2018). We demonstrate this technique through evaluations of speakers' statements' truth values (Sulkunen \& Törrönen, 1997a, 1997b). A speaker can assume a superior position in knowledge as compared to the (imagined) addressee. This undermines solidarity between speaker and addressee - a trait in a group discussion that might leave an impression of great disagreement or prevalence of negative attitudes by observing researchers.

In Group 4, the interviewees often confirmed what other colleagues had just stated in their previous utterance.

Interviewee 13: Yes. Well, the act of gambling is not yet satisfied at this point, with the early win.

Interviewee 12: Exactly. (Group 4)

Interviewee 12 knew this to be true, but also believed that her colleague was right and, in this way, acknowledged his expertise in the subject matter. In Group 1, however, the discussion more commonly involved expressions of doubt concerning colleagues' prior utterances.

Interviewee 1: Well, you could still ask, I think, you could offer the second one [character with gambling problems] to contact his bank. Well, in my opinion the most important [thing] with an addiction is that you do not hide it.

Interviewee 3: But would you really go to such length, realistically, at work that you would go together with him to the bank? (Group 1)

Here, Interviewee 3 indicated that she knew better and did not believe that Interviewee 1 would really offer this kind of support to a client. The speaker here placed herself as an expert above her colleague and questioned the colleague's professionalism. This kind of internal group conflict was common in Group 1; when doubts were raised in other groups they were addressed less often in constructs of doubt or contestation of colleagues' work expertise.

It seems that Groups 1 and 4 may have been equally negative with regard to the value of respect for persons and human capacities to change, but Group 4 had internal consensus and mutual support, whereas Group 1 showed proof of internal struggles between the participants. In comparison, in Group 3 one of the interviewees (Interviewee 6) did not share the majority's optimism with regard to capacity for change; however, this disagreement did not lead other group members to question her professionalism. Thereby, the technique of examining speakers' positions could clarify the absence of negative reactions in our initial impressions when analyzing the data from Groups 3 and 4 . This technique also substantiated our initial negative reaction toward Group 1, while the technique of quantifying expectations identified one of the group members as actually expressing an optimistic view on a person's capabilities to change.

\section{Discussion}

We have presented three techniques to make sense of the subjectivity in researchers' observations in focus-group interviews. The adapted summative content analysis (Hsieh \& Shannon, 2005) is easy to conduct, transparent, and reproducible. In fact, when using software for qualitative data analysis, searching for specific words and counting them can be automated. Focusing on words detached from their context nevertheless highlights the importance of recontextualization in order to avoid misinterpretations (Silverman, 2006).

The second technique on the quantification of expectations is already a step further in the direction of interpretative analysis. Consequently, it demands a prior assumptive categorization logic, as the researcher needs to decide on the categories to be coded and which passages of discussion to apply it to. It is nevertheless a transparent and modestly reproducible procedure as well. The first two techniques enlightened our subjective impressions concerning two of the focus groups (Groups 1 and 2), but at the same time they problematized our initial appraisal of the remaining two (Groups 3 and 4).

Our last technique, the analysis of speaker positions, helped to unfold and explain this observation. It is also recognizable that while our last technique is the most potent for qualifying researchers' initial subjective reactions to their data, it is also 
the most work-intensive to carry out. The technique of analyzing speaker positions is also the least affiliated with the leading positivist paradigm in addiction research. As such it is more difficult to accommodate than the first two techniques. Yet by clearly articulating and walking through the semiotic framework employed, this strategy can in a transparent fashion explain the underlying reasoning for the researcher's subjective impressions.

In qualitative addiction research practice, we recommend using these techniques when needed (e.g., the researchers have a strong subjective impression concerning their data) and to carry them out in a similar order as presented here. This way one achieves the best possible trade-off between depth and resources (e.g., time and writing space). One can progress onwards from the process of following one's subjective impressions, when the researcher's subjectivity has been clarified to a sufficient extent. "Sufficient," in this case, would be a relative concept, but a useful rule of thumb is to make the grounds of one's interpretations explicit (Stenius, Mäkelä, Miovský, \& Gabrhelík, 2017). In some cases, this might require an all-out elaboration of respondents' speaker positions, while in others the adapted summative content analysis might be enough.

Following our subjective impressions facilitated subsequent considerations, which should be understood as forming research questions for further studies more so than as final conclusions. We can consider participants' backgrounds in light of the German social work context. The participants of Group 2 were working in psychiatric services for children and adolescents. They had degrees in practical social work from a polytechnic. Thus, one could expect a more practical approach targeted at substituting children's material deficiencies (Schilling, 1997; Hering \& Münchmeier, 2000; Rauschenbach \& Züchner, 2011). Groups 1 and 4 also consisted of professionals who work with children and youth, but these interviewees had a more heavily theoretical education from university. Maybe one could speculate that the contradiction between their theoretical pedagogical education and the social work reality when faced with addictions led to a higher degree of frustration (Schilling, 1997; Hering \& Münchmeier, 2000; Rauschenbach \& Züchner, 2011). Their strategy to harmonize the contradiction was an adaptation of professional knowledge at the expense of social work's professional values (Blinkert, 1972). These hypothetical explanations should not be misunderstood as verdicts: social desirability may also be a contributing factor (e.g., Goffman, 1959). In the interview situation, participants were to some degree playing roles presenting their profession. Maybe the groups identified as more "negative" were in fact offering a more realistic view into the complex backstage of social work. Without having followed up on our subjective impressions, such matters would not have arisen for consideration.

Our proposed techniques for reflection and transparency are not exclusive to strategies like multiple coders or triangulation (e.g., Miles, Huberman, \& Saldana, 2014) and can be combined with these if deemed necessary. Often multiple use of such technologies can also be left to following analyses and studies (Alasuutari, 1996).
We have presented three techniques for assessing initial impressions of data, and for reflecting on them as part of the research conduct (Mauthner \& Doucet, 2003). While counting and coding have been controversial ways of dealing with qualitative data (e.g., Maxwell, 2010; Salo, 2015) this study indicates that quantification can help to provide an overview of data (Becker, 1970; Silverman, 2006). In order to please the positivist research paradigm in addiction research, qualitative researchers may be asked to refrain from the core logic of their own research paradigm. The processes within techniques suggested in this paper manage to retain researcher subjectivity, a central consideration in qualitative research, without abandoning the scientific rigor required in addiction publishing (Whittemore, Chase, \& Mandle, 2001; Hellman et al., in press). We consider it highly likely that the techniques can provide great value in analyses of other kinds of interview data as well, though this exceeds the scope of this particular study

\section{References}

Alasuutari, P. (1996). Theorizing in qualitative research: A cultural studies perspective. Qualitative Inquiry, 2(4), 371-384.

Babor, T. F., O’Reilly, J., Stenius, K., Pates, R., Miovský, M., \& Candon, P. (Eds.) (2017). Publishing addiction science. London, England: Ubiquity Press.

Bamford, T. (1990). The future of social work. London, England: Macmillan.

Banks, S. (2001). Ethics and values in social work. New York, NY: Palgrave.

Becker, H. (1970). Field work evidence. In H. Becker (Ed.), Sociological work: Method and substance (pp. 39-62). New Brunswick, Canada: Transaction Books.

Berends, L., \& Johnston, J. (2005). Using multiple coders to enhance qualitative analysis: The case of interviews with consumers of drug treatment. Addiction Research \& Theory, 13, 373-381.

Blinkert, B. (1972). Unvollständige Professionalisierung und Konflikte im Bereich Sozialarbeit. Zeitschrift für Soziologie, 4, 291-301.

Bryman, A. (2003). Quantity and quality in social research. New York, NY: Routledge. doi: 10.4324/9780203410028

Butrym, Z. (1976). The nature of social work. London, England: Macmillan Press.

Denzin, N. (1994). The art and politics of interpretation. In N. Denzin \& Y. Lincoln (Eds.), Handbook of qualitative research (pp. 500-515). Thousand Oaks, California: Sage.

Egerer, M. (2010). Gate keepers' images of addiction in Finland, France, and Germany. The film-clips in the group interviews. Helsinki, Finland: University of Helsinki, Department of Social Research.

Egerer, M. (2015a). Images of problem drinking and gambling. German social workers' view on selfgoverned drinking and game providers' profit motives. Part 1. Soziale Arbeit 3, 102-107.

Egerer, M. (2015b). Images of problem drinking and gambling. German social workers' view on selfgoverned drinking and game providers' profit motives. Part 2. Soziale Arbeit 4, 142-149. 
Geertz, C. (1973). The interpretation of cultures: Selected essays. New York, NY: Basic Books.

Goffman, E. (1959). The presentation of self in everyday life. New York, NY: Anchor.

Golafshani, N. (2003). Understanding reliability and validity in qualitative research. The Qualitative Report, 8(4), 597-606.

Guest, G., MacQueen, K. M., \& Namey, E. E. (2012). Applied thematic analysis. Thousand Oaks, CA: SAGE Publications, Inc. doi:10.4135/9781483384436

Hellman, M., Kauppila, E., Katainen, A., Kettunen, T. A., Saitz, R., \& Calver, K. (in press). Diversity in addiction publishing. International Journal of Drug Policy.

Hering, S., \& Münchmeier, R. (2000). Geschichte der Sozialen Arbeit. Eine Einführung. Munich, Germany: Juventa.

Holsti, Ole. R. (1969). Content analysis of the social sciences and humanities. Reading, Massachusetts: Addison Wisely Publishing Company.

Hsieh, H. \& Shannon, S. (2005). Three approaches to qualitative content analysis. Qualitative Health Research, 15(9), 1277-1288.

Hubbard, G., Backett-Milburn, K., \& Kemmer, D. (2001). Working with emotion: Issues for the researcher in fieldwork and teamwork. International Journal of Social Research Methodology, 4(2), 119-137.

i Cancho, R. F., \& Solé, R. V. (2001). Two regimes in the frequency of words and the origins of complex lexicons: Zipf's law revisited. Journal of Quantitative Linguistics, 8(3), 165-173.

Kleinman, S., \& Copp, M. A. (Eds.). (1993). Emotions and fieldwork. Newbury Park, CA: SAGE Publications, Inc. doi:10.4135/9781412984041

Krieger, S. (1985). Beyond "subjectivity": The use of the self in social science. Qualitative Sociology, 8(4), 309־324.

Laughey, D. (2007). Key themes in media theory. London, England: McGraw-Hill Education (UK).

Lindh, J. (2015). Antropologin refleksiivisyys tutkijan oppimisena. In S. Aaltonen \& R. Högbacka (Eds.), Umpikujasta oivallukseen. Refleksiivisyys empiirisessä tutkimuksessa (pp. 35-60). Tampere, Finland: Tampere University Press.

Mauthner, N., \& Doucet, A. (2003). Reflexive accounts and accounts of reflexivity in qualitative data analysis. Sociology, 37(3), 413-431.

Maxwell, J. (2010). Using numbers in qualitative research. Qualitative Inquiry, 16(6), 475-482.

Miles, M., Huberman, M., \& Saldana, J. (2014). Qualitative data analysis. A methods sourcebook (3rd ed.). London, England: Sage.

Neale, J., Hunt, G., Lankenau, S., Mayock, P., Miller, P., Sheridan, J., . . . Treloar, C. (2013). Addiction journal is committed to publishing qualitative research. Addiction, 108, 447-449.

Rauschenbach, T., \& Züchner, I. (2011). Berufs- und Professionsgeschichte der Sozialen Arbeit. In H. Otto \& H. Thiersch (Eds.), Handbuch. Soziale Arbeit (pp. 131142). Munich, Germany: Reinhardt.

Rhodes, T., Stimson, G. V., Moore, D., \& Bourgois, P. (2010). Qualitative social research in addictions publishing: Creating an enabling journal environment. The International Journal on Drug Policy, 21(6), 441.

Runcieman, A. J. (2018). Carrying out research in the field. In A. J. Runcieman (Ed.), The identity of the professional interpreter (pp. 51-69). Singapore: Springer.

Salo, U. (2015). Simsalabim, sisällönanalyysi ja koodaamisen haasteet. In S. Aaltonen \& R. Högbacka (Eds.), Umpikujasta oivallukseen. Refleksiivisyys empiirisessä tutkimuksessa (pp. 166-190). Tampere, Finland: Tampere University Press.

Schilling, J. (1997). Soziale Arbeit. Entwicklungslinien der Sozialpädagogik/Sozialarbeit. Berlin, Germany: Luchterhand.

Silverman, D. (2006). Interpreting qualitative data (3rd ed.). Los Angeles, CA: Sage.

Spencer, R., Pryce, J., \& Walsh, J. (2014). Philosophical approaches to qualitative research. In P. Leavy (Ed.), The Oxford handbook of qualitative research. doi:10.1093/oxfordhb/9780199811755.013.027

Stenius, K., Mäkelä, K., Miovský, M., \& Gabrhelík, R. (2017). How to write publishable qualitative research. In T. F. Babor, K. Stenius, R. Pates, M. Miovský, J. O'Reilly, \& P. Candon (Eds.), Publishing addiction science: A guide for the perplexed (pp. 155-172). London, England: Ubiquity Press.

Strauss, A. (1987). Qualitative analysis for social scientists. Cambridge, England: Cambridge University Press.

Sulkunen, P., \& Egerer, M. (2009). Reception analytical group interview: A short introduction and manual. Helsinki, Finland: University of Helsinki, Department of Sociology.

Sulkunen, P., \& Törrönen, J. (1997a). Constructing speaker images: The problem of enunciation in discourse analysis. Semiotica, 115(1/2), 121-146.

Sulkunen, P., \& Törrönen, J. (1997b). The production of values: The concept of modality in textual discourse analysis. Semiotica, 113(1/2), 43-69.

Tong, A., Sainsbury, P., \& Craig, J. (2007). Consolidated criteria for reporting qualitative research (COREQ). International Journal for Quality in Health Care, 19, 349-357.

Törrönen, J. (2002). Semiotic theory on qualitative interviewing using stimulus texts. Qualitative Research, 2(3), 343-362.

Whittemore, R., Chase, S., \& Mandle, C. (2001). Validity in qualitative research. Qualitative Health Research, 11, 522-537. 